\title{
Managing Security in the Built Environment - A Review of Environmental Crime Prevention Strategies
}

\author{
C. HANNAH, ${ }^{*}$ S. TADEPALLI AND P. GOPALAKRISHNAN \\ *Doctoral Research Scholar at Department of Architecture, National Institute of \\ Technology, Tiruchirappalli, Tamil Nadu - 620015, India
}

*Email: hannahchristo@gmail.com

November 4th, 2014 | January 12th, 2015 | January 14th, 2015

Published online: January 21, 2015

The Author(s) 2015. This article is published with open access at www.chitkara.edu.in/publications

\begin{abstract}
The practice of urban planning and building design largely follow traditional methods while transforming the structure and quality of life in the built environment. The process of managing cities requires updates and integration of new technologies and research efforts. In this context, development of smart, sustainable, energy efficient, healthy, safe and secure built environment is a priority that is shaping modern cities all over the world. Though management of Indian cities tries to address these issues to a certain extent, it can be said that, as compared to many developed countries, aspects of safety and security have not been the top priority of our planners and designers. Research on Environmental Criminology and Environmental Psychology clearly indicates the important role and benefits of crime prevention through appropriate design of the built environment. In this context, this paper highlights the role of crime prevention strategies and the relevance of environmental criminology in current building practices for addressing security concerns in India.
\end{abstract}

Keywords: Environmental Criminology, Fear of Crime, Crime Prevention Strategies

\section{INTRODUCTION}

Crime and antisocial behavior are gaining attention because they cause potential death, injury, fear, damage, inconvenience and huge financial loss. The stimuli to crime and fear of crime are said to have roots in the social and cultural setting of the urban space. The interplay of population explosion, rapid urbanization, globalization, environmental degradation, social conflicts and anonymity challenges the security of a place, resulting in crime.

Studies in criminology define crime as an event caused by the concurrence of (i) legal criteria that maintains social order, (ii) an offender who breaks this law, (iii) a vulnerable target and, (iv) the physical setting (Brantingham \& Brantingham, 1981). A range of responses such as design strategies, community action and law enforcement are required to combat crime and fear of crime. Environmental Criminologists study the time, place, spatial and behavioral patterns and targets of crimes and offenders. Research on Environmental

Creative Space Vol. 2, No. 2, January 2015 pp. 141-156

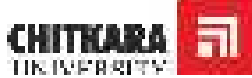

(C)2015 by Chitkara University. All Rights Reserved. 
Hannah, C. Tadepalli, S. Gopalakrishnan, P.
Criminology and Psychology has formulated various theories, concepts and approaches to crime prevention, such as 'Defensible Space' (Newman, 1972), 'Crime Prevention through Environmental Design' (Jeffery, 1971), 'Routine Activity' (Cohen \& Felson, 1979), 'Rational Choice Model' (Clarke \& Cornish, 1985), 'Environmental Criminology' (Brantingham \& Brantingham, 1981), 'Prospect and Refuge' (Fisher \& Nasar, 1992), 'Hot Spots' (Sherman, 1995), 'Broken Windows' (Coles \& Kelling, 1996), 'Crime Displacement' (Barr \& Pease, 1990) and, 'Crime Mapping' (Brantingham \& Brantingham, 1998) as measures to understand crime in urban environments. All of the above highlight that safety and security are an integral part of the environment quality and that design of building elements and spaces offer effective approaches to crime prevention and improvement of community safety.

In India, however, the understanding of Environmental Criminology is limited to administrators of law and order. Wider application of the same to the design of built spaces is negligible. Hence there is a need to integrate spatial dimension with traditional security measures to manage crime prevention in built environment.

\section{ENVIRONMENTAL CRIMINOLOGY - THE THEORETICAL BACKGROUND}

Crime continues to be an unfortunate aspect of life since ancient days. History describes the practice of crude self-protection and crime prevention techniques by several early societies. Use of natural and manmade tools and community togetherness were used as protection techniques against attacks. Early dwellings used the lower floors for daytime activities and the more secure upper floors for rest and slumber at night. The inhabitants would further control night-time access to upper floors by use of retracting ladders. Settlements located on mountain tops utilized the natural element of height offered by the environment for protection. Ancient societies also constructed structural elements like forts and moats to define boundaries and protect citizens from enemies. Thus height, distance and light were the conventional design features that were used to manage needs of defence and security. This establishes the use of physical environment for defence and protection since early days.

Design of the physical environment is also known to impact the prevention of crime. The study of this relationship between crime and physical environment is called Environmental Criminology. The past four decades have seen extensive research by environmental criminologists, urban and environmental planners to empirically analyse this link and establish connections between them. These studies project the complexity of crime and how it can vary significantly at different levels of spatial and temporal resolution. 


\subsection{The Built Environment}

Crime is all about a criminal's needs, the victim's vulnerability and the setting that modifies an individual's perception and response. Both criminals and victims construct mental templates or holistic images of the environment and perceive or respond to threats and opportunities accordingly. Criminals construct templates of sites, using them to select targets, place and time (MacDonald \& Gifford, 1989). The victims also, based on their prior experience, personality and exposure, create a rational template identifying and associating every kind of object, place and situation with threat or reward. When a location or the situation is appraised based on this mental image, it alters behaviour.

The environmental setting shapes the degree of visibility and permeability, determining 'how much can be seen' and 'how far can one move'. The physical environment modifies opportunities for crime, levels of risk and the guardian effect. Hence, crime must be viewed in the context of the place where it occurs (Newman, 1972). The environment around us gives cues about the characteristics and shape of the immediate backcloth (Brantingham $\&$ Brantingham, 1993). Crowe (2000) prompts evidently that negative cues produce fear and avoidance behaviors, while positive cues produce desired responses and behaviors. Macro elements such as specific land use, street layout, disorder and deterioration, physical entrapments and block visibility also have an effect on incidents and patterning of crime (Moffat, 1983) (Brantingham \& Brantingham, 1981) (Greenberg \& Rohe, 1984) (Clarke, et al., 1976) (Clarke \& Mayhew, 1980). Micro units of analysis like buildings, block faces and, street segments act as crime generators, attractors or arresters (Sherman, et al., 1989) (Eck \& Weisburd, 1995). Thus manipulation of the built environment can reduce opportunities for crime (Jeffery, 1971) (Newman, 1972).

\section{CRIME PREVENTION THEORIES}

Traditional criminology analyses types of crime and social backgrounds of criminals. Environmental Criminology differs from this by studying the same, but giving emphasis to the locational context of crimes. Environmental Crime Prevention Methods focus on the settings for crime, rather than the crime or criminals. These attempt to evaluate and predict the occurrence of crime and introduce design and planning interventions to manage, change or reduce the opportunity for crimes. The recognized crime prevention theories, focusing on the link between environmental design and human security, can be classified under 'Location-based Classical Theories' and 'Multi-factor Environmental Criminology Theories'.
Managing Security

in the Built

Environment

- A Review of

Environmental

Crime Prevention

Strategies i 
Hannah, C.

Tadepalli, S.

Gopalakrishnan, P.

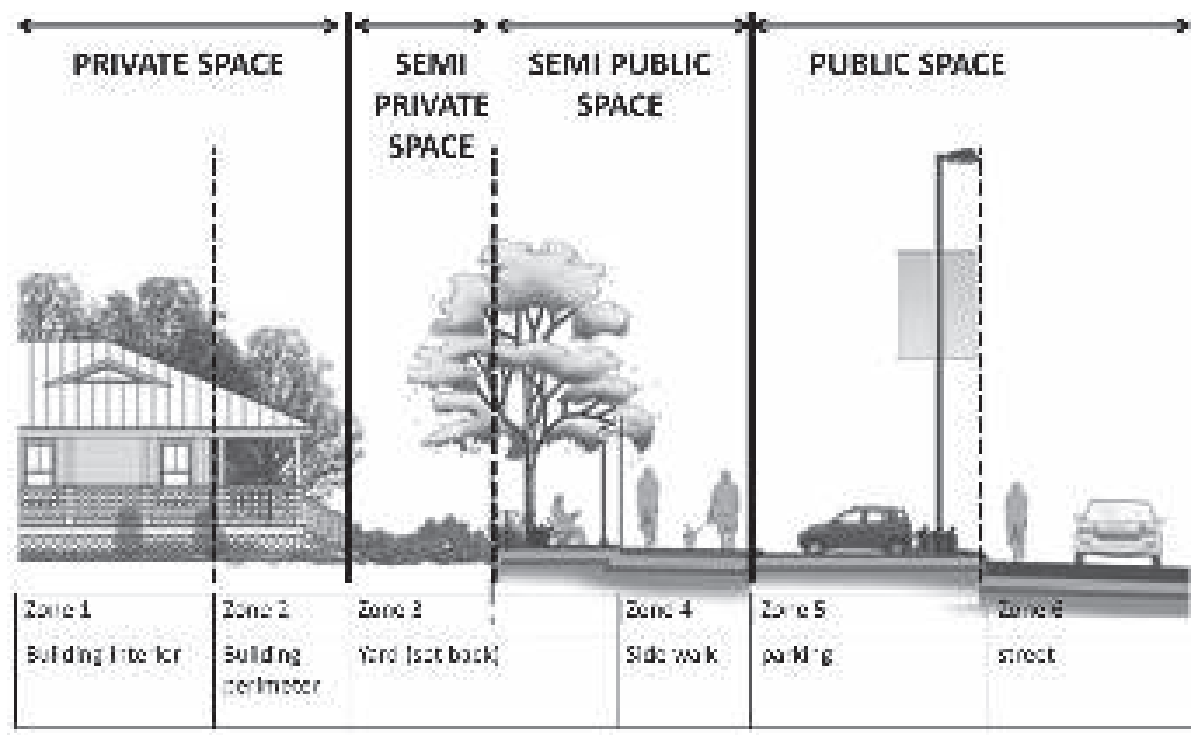

Figure 1: An example of delineation of Private, Semi Private, Semi Public and Public spaces.

\subsection{Social Science Theories on Spatial Location of Crime}

In 1764, the criminologist Cesare Beccaria explained the concept of free will in his essay 'Crimes and Punishments,' elaborating the deterrent effect of punishment on crime. The 'Rational Choice Deterrence Theory' stated that crime is seen as a choice that is influenced by its costs and benefits (Clarke $\&$ Cornish, 1985). Following that, Cohen and Felson (1979) developed the 'Routine Activities Theory'. This theory proposed that crime occurs when there is an intersection of a motivated offender, an attractive target, and a lack of capable guardianship (Cohen \& Felson, 1979). The routine activity theory related the pattern of offence to everyday patterns of social interaction. It thus explained the dramatic rise in crime during the 1960s, stating absence of guardianship as the reason. The impact of spatial details on the distribution of crimes, as observed in these two theories, gave birth to the discipline 'Environmental Criminology'.

\subsection{Urban Design Theories on Site-specific Cues Impacting Crime}

The initial connection between environmental design and perceived safety was recorded by Jane Jacobs in early 1960s (Jacobs, 1961). Following her 
research findings, the 'Federal Housing Act and Safe Streets Act' passed by the US government, included Environmental Criminology in Urban Design. Conventional studies then focused on macro-level relationships. But, recent studies also focus on meso-level and micro-level relationships to identify and understand the impact of architecture and urban design on crime.

\subsubsection{Defensible Space Theory}

The Defensible Space Theory was framed by the architect, Oscar Newman. After analyzing more than 100 American public housing projects, Oscar Newman attributed lay-out, size of the projects and poor access control as primary reasons for high crime rates (Newman, 1972) (Newman, 1996). The Defensible Space Model argues that a planned physical space can reinforce social structures and defend crime. His results were mirrored in other studies emphasizing the dependability on defensible space characteristics for safer spaces. Newman suggested four key elements, (i) Territoriality, (ii) Natural Surveillance, (iii) Image and, (iv) Milieu, as strategies for crime prevention. He also identified four types of zones, (i) Public Space, (ii) Semi-public Space, (iii) Semi-private Space and, (iv) Private Space to define legitimate and illegitimate users (Fig. 1).

This theory was criticized for ignoring social elements of tenants (Taylor, et al., 1985) (Merry, 1981). His work was also blamed for environmental determinism. His theory covered possibilities of external threats, but ignored prospects of crime committed by legitimate users of the space. However controversial, this work gave direction to further research that advocated the importance of accessibility, land use, lighting, street activity and proximity to transportation routes on crime reduction (Schneider \& Pearcey, 1996).

\subsubsection{Prospect and Refuge Theory}

Prospect-Refuge Theory, proposed by Fisher and Nasar in 1992, says that environments afford a certain amount of Prospect (long lines of sight, wide angle of view) and Refuge (multiple exit points close at hand) (Fig. 2). This prospect and refuge affect people's perception of how safe an environment appears to be (Fisher \& Nasar, 1992). It was further expanded that entrapment and concealment also increases vulnerability of targets (Nasar, et al., 1993). Thus, a setting that ensures complete visibility of the surroundings, without exposing the individual, is termed a secure place. Lighting, access, openness, novelty, complexity and order are variables that are reported to impact the prospect and refuge of a place (Nasar, 1988) (Loewen, et al., 1993).
Managing Security in the Built Environment - A Review of Environmental Crime Prevention Strategies 
Hannah, C.

Tadepalli, S.

Gopalakrishnan, P.

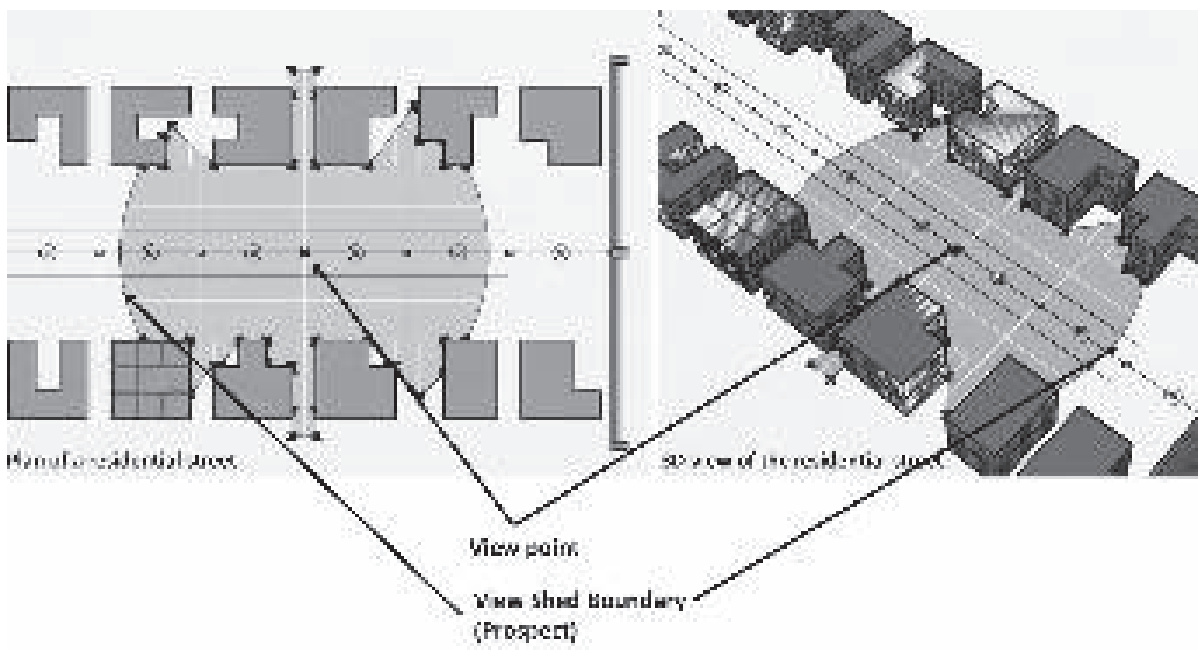

Figure 2: Prospect for a point on a street, measured using Isovist

\section{CRIME PREVENTION STRATEGIES}

The link between crime and the built environment is explained by (i) the 'hardware rationale' that focuses on target-hardening aspects like compound walls and locks, to name a few, (ii) the 'community building rationale,' which is built on the hypothesis that increased lighting, controlled access and defined boundaries reduce crime and, (iii) the 'social surveillance rationale,' which presumes that the layout of the physical environment can provide guardianship and, thus, reduce crime (Motoyama, et al., 1980). Several approaches like 'Situational Crime Prevention' (SCP), 'Crime Prevention through Environmental Design' (CPTED), 'Secured By Design' (SBD), 'Safe, Healthy and Positive Environmental Desig'n (SHAPED), 'Designing Out Crime,' 'Crime Opportunity Profiling of Streets' (COPS) and, 'Situational Crime Reduction in Partnership Theory' (SCRIPT) give design guidelines to address the issue of crime and fear of crime. The two distinct models among them are 'Situational Crime Prevention' (SCP) and 'Crime Prevention through Environmental Design’ (CPTED).

\subsection{Situational Crime Prevention (SCP)}

Situational Crime Prevention (SCP) is an environmental design approach developed in the 1970s by the British government's criminological research 


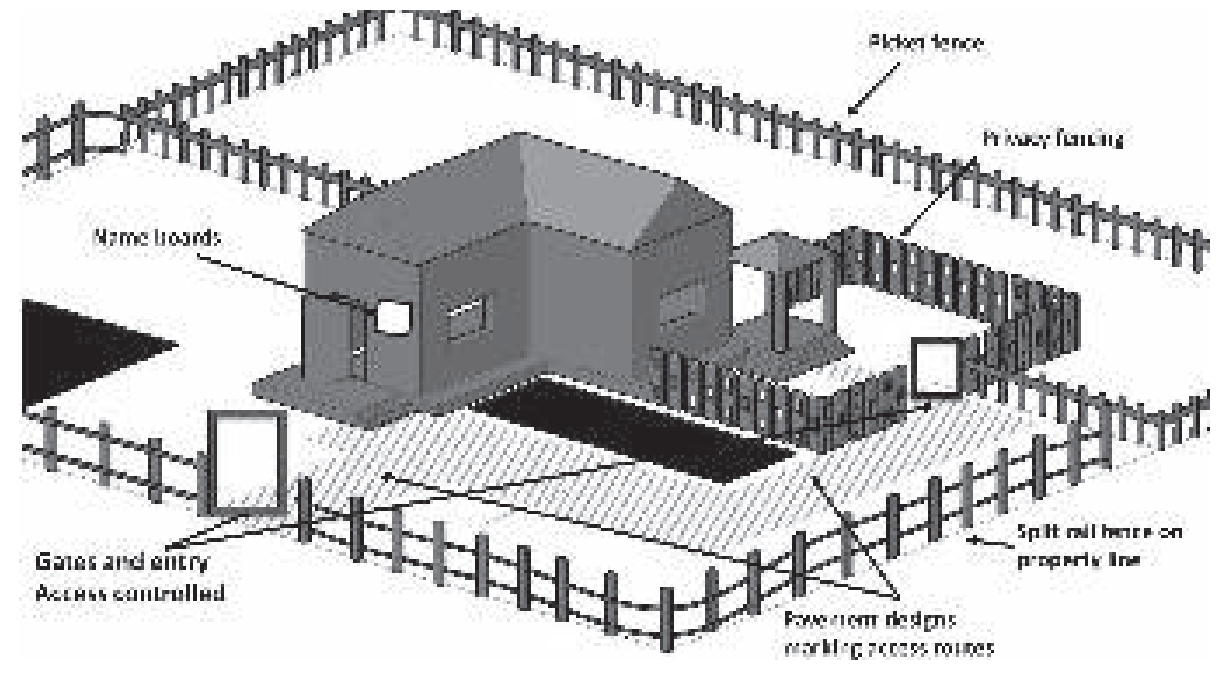

Managing Security in the Built Environment - A Review of Environmental Crime Prevention Strategies

Figure 3: Features that help increase territoriality

department. This is a general approach to reduce the opportunities for any kind of crime, occurring in any kind of setting. The four categories under which it accomplishes crime prevention include increasing perceived effort, increasing perceived risks, reducing anticipated rewards and removing excuses. It lists out sixteen opportunity reduction techniques under these categories (Clarke, 1997). The strategies followed by Situational Crime Prevention include Target Hardening, Deflecting Offenders, Controlling Access, Controlling Crime Facilitators and many more.

\subsection{Crime Prevention Through Environmental Design (CPTED)}

The term CPTED was coined by the criminologist, C. Ray Jeffery in 1971 (Jeffery, 1977) . He argued that biological and environmental determinants were overlooked because of the exaggerated importance given to social causes of crime. The original CPTED model was a 'stimulus-response model' that was based more on the biological aspect. It evolved into a general crime prevention model as it became an integrated-systems approach, and, can now be related to management, design or manipulation of the immediate environment in which crimes occur in a systematic and permanent way (Paulsen \& Robinson, 2004). CPTED considers three functions of human space namely (i) 'Designation' 
Hannah, C. Tadepalli, S. Gopalakrishnan, P.

or the intended use of space, (ii) 'Definition' of the space that includes its social, cultural, legal, and psychological definitions and, (iii) 'Design'. CPTED explains this idea under six categories - Territoriality, Access Control, Surveillance, Target Hardening, Activity Support and Maintenance. The former four categories address the spatial structuring of locations while the latter two address presence and involvement of people (Crowe, 2000).

'Territorial Reinforcement' is the strategy of using physical design to create a sphere of influence that can draw a clear delineation between private space and public spaces. The sense of ownership over this territory increases responsibility to overlook the space and keeps intruders away. Territoriality as a strategy was introduced by Newman (1972) and was established as a functioning concept, complementing defensible space (Brower, et al., 1983). Territoriality thus increases natural guardianship, natural congregation and natural defensibility (Taylor, et al., 1981). Property lines, landscape plantings, pavement designs, gateway treatments and fences are the devices that help draw boundaries (Fig. 3). Nonetheless, gated communities have lower territorial definition yet enjoy greater sense of security (Doenges, 2000). This conflict questions the priority of a stable neighborhood over territoriality. Again, features like fencing and gate-keeping, categorized under territoriality create isolation and hence contradicts with guidelines specified under visibility and surveillance factors.

'Access Control' is the design concept that discourages access to places by increasing the effort and risk for offenders to reach the target locations. Legibility, permeability, exposure and enclosure are the core design elements manipulated to create a naturally defensible space (Samuels, 2011). Barriers like bollards, gates and fences, hardware component including locks, chains, burglar bars, alarms, streets, sidewalks, building entrances, vertical movement indicators like staircase, horizontal movement indicators like external balconies and terraces are entities of access control. Careful placement and orientation can design out crime. Connectivity between buildings and set back details also play a part in access control design. Permeable street layouts that minimize the opportunity for entrapment, but support escape and stringently controlled entries and exits that hinders movement of legitimate users, are examples of conflict within strategies.

'Surveillance Design' is about maximizing visibility by design and orientation of building façades and activity spaces in relation to the public realm. Lighting, police patrol, mechanical surveillance and regulated traffic are measures to enhance surveillance. Clear sightlines are also a powerful situational deterrent (Fig. 4). Street activity and population density are reported to be variables that predict surveillance (Angel, 1968). Integrated and 


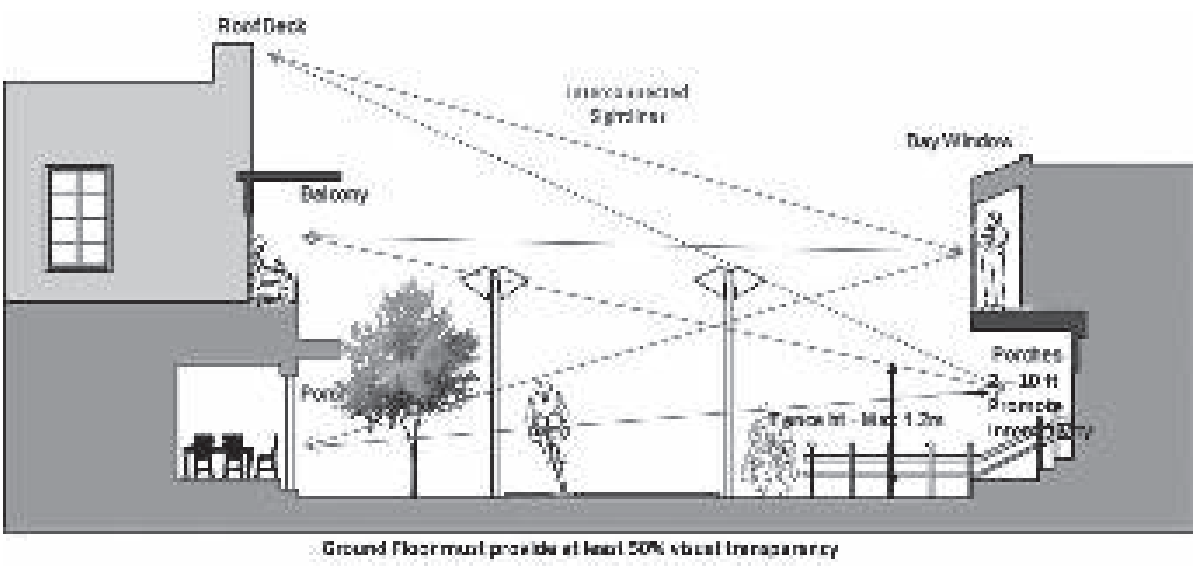

Managing Security in the Built Environment - A Review of Environmental Crime Prevention Strategies

Figure 4: Interconnected sightlines increase surveillance.

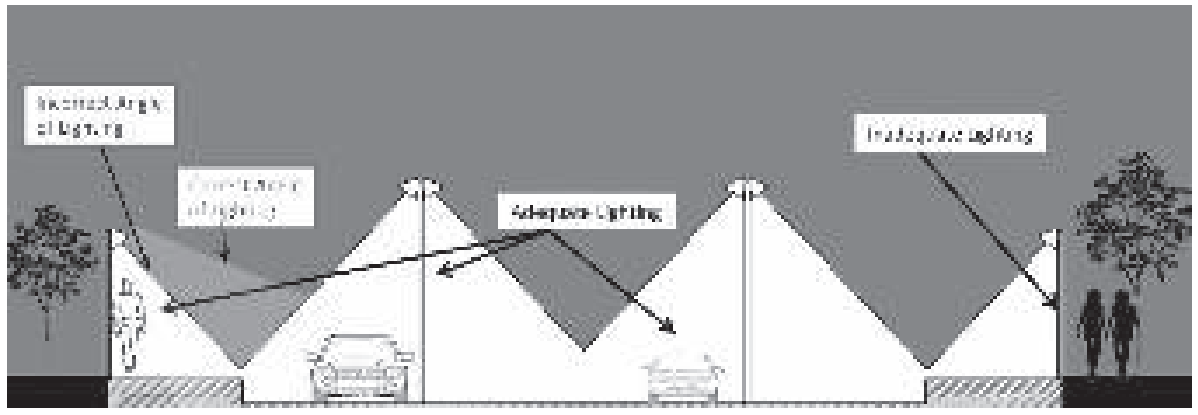

Figure 5: Ample lighting is necessary to ensure good surveillance.

connected spaces are reported safe because of the thorough movement and strong inter-visibility (Hillier \& Shu, 2000). The importance of lighting has also been highlighted in studies (Atkins, et al., 1991) (Ramsay, 1991) (Fig. 5). Electronic surveillance (Clarke, et al., 1991), guardians, neighbors, passersby (Sorensen, 2003), security guards and policing (Hannan, 1982) resulted in reduced crime. Geometry and configuration of the built environment exert a major effect on visibility. Heights of buildings, widths of streets, design and color of edge buildings, urban square syntax, tree canopies and night lights impact visible permeability and perceived ambience (Samuels, 2011). 
Hannah, C.

Tadepalli, S.

Gopalakrishnan, P.

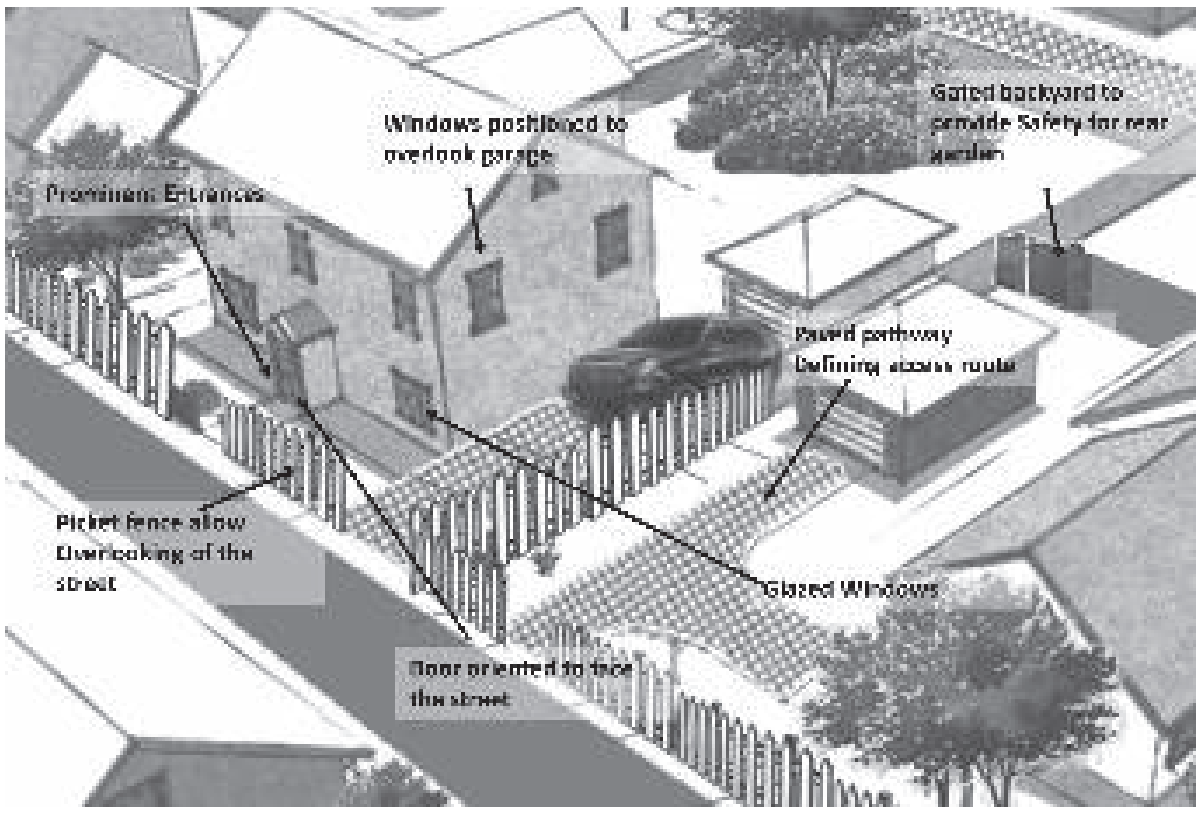

Figure 6: Target hardening techniques that increase the defensibility of a space.

'Target Hardening' is a 'designing out crime' technique that tries to reduce opportunity and make crime unprofitable and laborious (Fig. 6). Significantly, glazing in windows, installation of mechanical surveillance tools like CCTV cameras and door alarms are unambiguous solutions that increase the risk factor for criminals without disturbing other crime prevention strategies. Relying solely on the physical barriers as target hardening solution obstructs sightlines, provides hidden recesses and prevents access. It strengthens territoriality but disturbs the balance by minimizing surveillance and permeability.

'Maintenance' is one feature that portrays buildings or an urban space as crime generators, attractors or neutralizers. Misdemeanors, delinquent acts, disorder, dumped trash, vandalized buildings and graffiti indicates malaise and are termed as incivilities (Taylor, 1999). Inattention and signs of physical despair, as described under the broken window hypothesis, encourage further mishap (Wilson \& Kelling, 1982). It states that these locations increase vulnerability by depriving the sense of territorial domain, even if offences are not committed in these locations. Hence, this factor relates to both crime and fear of crime.

These strategies aim to structure the physical environment to prevent crime and reduce fear of crime. Several studies note that building elements have 
varying degree of impact on crime. The strategies thus give design guidelines regarding the use of these building elements and organization of spaces to reduce crime in the neighborhood.

\section{STUDIES ON FEAR OF CRIME}

The physical setting directly or indirectly impacts people's perception of risk and fear of crime. Fear of crime as a distinct field of criminological research dates back to the late 1960's, its origin sighted in Lyndon Johnson's Crime Survey (Hardyns \& Pauwels, 2010). Environmental factors are considered common to studies on both crime prevention and fear of crime. Hence, crime prevention strategies like Surveillance, Territoriality, Access Control, Target Hardening and Maintenance are factors analyzed by studies on fear of crime as well. The three categories of urban places generating fear of crime include (i) locations with fear generating functions or features, (ii) locations which are neglected or badly maintained and, (iii) locations with problematic urban design (Soomeren, 2002). Criminologists and psychologists analyze the impact of location on fear of crime by considering 'vulnerability' and 'perception of risk' in addition to other indicators of crime. Fear of crime is a social problem that can affect the quality of life. It restricts movements, and thus, modifies the zoning of a city (Hale, 1996) (Lavrakas, 1982). Hence, the fear of crime should also be addressed while planning security measures.

\section{THE INDIAN SCENARIO}

Crime prevention concepts are being extensively applied in countries like the United States and Britain. But, its applicability in countries like India is negligible. Crime mapping as a spatial analysis technique for analysing the spatial pattern of crime is a recent addition in modelling the crime scenario in India. A study that mapped crime revealed that hotspots are relatively high in densely populated areas, city centres and, transportation hubs (M.VijayKumar \& C.Chandrasekar, 2011). Employment-rate is reported as another factor affecting crime clustering and distribution of crime (Shafeeq \& Binu, 2014). The importance of such studies in establishing a measure for crime analysis has thus been pointed out (Jaishankar, et al., 2001).

The results of these macro-level studies, reporting impact of physical environment on crime, fall in line with existing literature. One micro-level study analysed building geometry and reported that the type of enclosure and ease of access impacted the perception of natural surveillance, thereby emphasizing the applicability of CPTED guidelines in the Indian context (Hannah, et al., 2013). Analysis of crime trends in and around Coimbatore using data from First Information Reports (FIRs) revealed that burglaries
Managing Security in the Built Environment - A Review of Environmental Crime Prevention Strategies 
Hannah, C.

Tadepalli, S.

Gopalakrishnan, P.

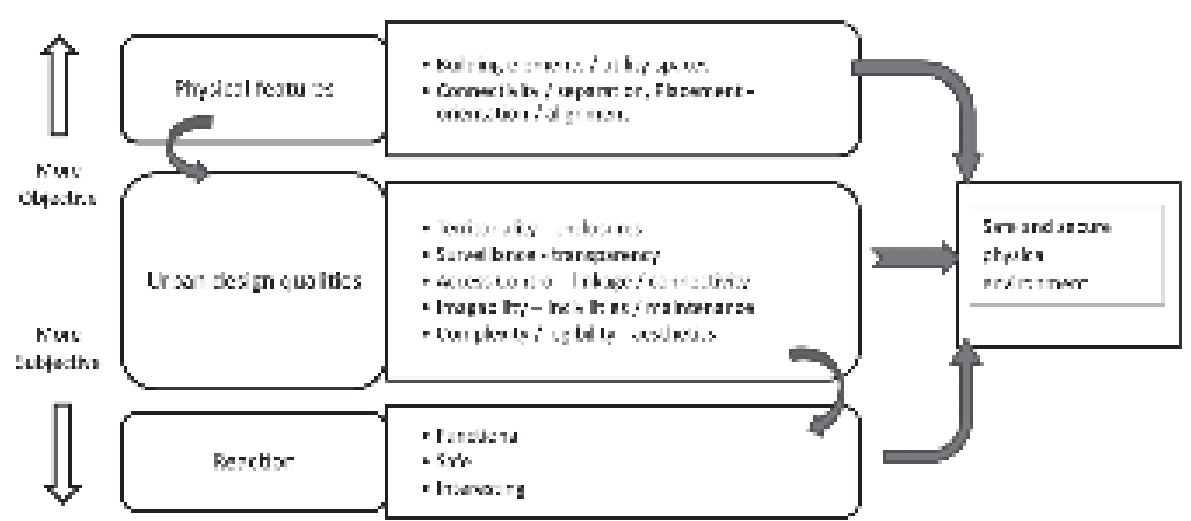

Figure 7: A summary of the links between environmental conditions and emotional responses.

occur more in suburban and middle class residential areas and less in rural and densely populated city areas highlighting similarities with previous literatures (Jayamala, 2008). The study of fear of crime at bus shelters revealed a strong relationship between nonphysical features and fear. However, a significant relationship between fear of crime and physical characteristics of bus shelters was not established (Subbaiyan \& Tadepalli, 2012). Also, a study on the impact of victimization on fear of crime revealed results contradicting with western literature (Nalla, et al., 2011). Results of some studies confirm the relevance of crime prevention strategies, while others report contradicting results, thereby possibly questioning the relevance of accepted theories. This variation in results may be attributed to the difference in the social structure of developing countries such as India and other developed nations. Conclusions, however, cannot be derived based on such a limited number of studies.

\section{SUMMARY}

The design of safe and secure urban neighborhoods through environmental crime prevention strategies are featured regularly in urban design literature affirming its increasing relevance. Crime prevention strategies support, with evidence, the effectiveness of incorporating design changes in the built environment to reduce crime (Fig. 7). It promotes collaboration across different sectors like law, design and psychology, thereby encouraging improved resource allocation and increased 
commitment to prevention of crime. Several studies list design guidelines for planning a crime free environment. Recent advances in computational modeling tools such as Virtual reality, Space Syntax, Isovist and Agent Modeling complement these studies to address existing and emerging issues of crime.

In spite of the strong link established between crime and built environment, a few obstacles limit its practical application. In some cases, guidelines suggested by different crime prevention strategies can contradict with each other. This can be attributed to the fact that many of these studies are conducted in isolation and for a specific type of crime. Also, the crime prevention guidelines detailed out by these studies dot yet qualify as zoning ordinances or building regulations.

Future research is expected to identify intelligent solutions integrating all strategies to provide unified guidelines. These guidelines can be adapted into an effective set of regulations or policies which can then be used in 2D and 3D computational analyst tools to aid urban planners and architects in their design and practice directly.

\section{REFERENCES}

[1] ANGEL, S., (1968) Discouraging Crime Through City Planning. Berkeley: Institute of Urban \& Regional Development.

[2] ATKINS, S., HUSAIN, S. \& STOREY, A., (1991) The influence of street lighting on crime and fear of crime - crime prevention unit paper no. 28. London: Home Office Crime Prevention Unit.

[3] BRANTINGHAM, P. J. \& BRANTINGHAM, P. L., (1981) Environmental Criminology. United States of America: Sage Publications.

4] BRANTINGHAM, P. J. \& BRANTINGHAM, P. L., (1993) Nodes. Paths and Edges: Considerations on Environmental Criminology. Journal of Environmental Psychology, Volume 13, pp. 3-28. Available from: http://dx.doi.org/10.1016/S0272-4944(05)80212-9

[6] BRAnTINGHAM, P. L. \& BRANTINGHAM, P. J., (1998) Mapping Crime for Analytic Purposes: Location Quotients, Counts, and Rates. In: D. M. DAVID WEISBURD, ed. Crime Prevention Studies, vol. 8. : . Monsey, New York: Criminal Justice Press.

[7] BROWER, S., DOCKETT, K. \& TAYLOR, R. B., (1983) Residents' perceptions of territorial features and perceived local threat. Environment and Behavior, 15(4), pp. 419-437. Available from: http://dx.doi.org/10.1177/0013916583154002

[8] CLARKE, R. V., (1997) Situational Crime Prevention: Successful Case Studies. Guilderland, New York: Harrow and Heston.

[9] CLARKE, R. V., HOUGH, M., MAYHEW, P. \& STURMAN, A., (1976) Crime as Opportunity. Home Office Research Study No. 34, London: H.M.S.O.

[10] CLARKE, R. V. \& MAYHEW, P., (1980) Designing out Crime. London: H.M.S.O.

[11] COLES, C. \& KELling, G., (1996) Fixing Broken Windows: Restoring Order And Reducing Crime In Our Communities. New York: The Free Press.

[12] CROWE, T., (2000) Crime Prevention Through Environmental Design: Applications of Architectural Design and Space Management Concepts. Boston: Butterworth-Heinemann.
Managing Security in the Built Environment - A Review of Environmental Crime Prevention Strategies 
Hannah, C.

Tadepalli, S. Gopalakrishnan, P.
[13] DOENGES, G. W., (2000) An exploration of sense of community and fear of crime in gated communities. Environment and Behavior, 32(5), pp. 597-611. Available from: http://dx.doi. org/10.1177/00139160021972694

[14] ECK, O. E. \& WEISBURD, D., (1995) Crime and place. Monsey, N.Y: Criminal Justice Press.

[15] FISHER, B. S. \& NASAR, J. L., (1992) Fear of Crime in Relation to Three Exterior Site Features: Prospect, Refuge, and Escape. Environment and Behavior, 24(1), pp. 35-65. Available from: http://dx.doi.org/10.1177/0013916592241002

[16] GREENBERG, S. \& ROHE, W., (1984) Neighborhood Design and Crime. APA Journal, pp. Vol. 50:1, pp. 48-61.

[17] HALE, C., (1996) Fear of Crime: A Review of the Literature. International Review of Victimology, Volume 4, pp. 79-150. Available from: http://dx.doi.org/10.1177/026975809600400201

[18] HANNAH, C., TADEPPALLI, S. \& SUBAIYAN, G., (2013) Computer aided modular geometric modeling, to study the perception of safety. Singapore, s.n.

[19] HILliER, B. \& SHU, S., (2000) Crime and urban layout: the need for evidence. In: V. MACLAREN, S. BALLANTYNE \& K. PEASE, eds. Crime Prevention and Community Safety. London: Institute of Public Policy Research, p. 224-248.

[20] JACOBS, J., (1961) The Death and Life of Great American Cities. New York: Random House.

[21] JAISHANKAR, K., SHANMUGAPRIYA, S. \& V.BALAMURUGAN, (2001) Crime mapping in India: A GIS Implementation in Chennai City Policing. Texas, Dallas, USA, s.n.

[22] JAYAMALA, M., (2008) Trends and Spatial Patterns of Crime in India: A Case Study of a District in India, s.1.: s.n.

[23] JEFFERY, C. R., (1971) Crime Prevention Through Environmental Design. Beverly Hills, CA: SAGE Publications.

[24] JEFFERY, C. R., (1977) Crime Prevention through Environmental Design. Beverly Hills, CA: Sage publications.

[25] LAVRAKAS, P., (1982) Fear of Crime and Behavioral Restrictions in Urban and Suburban Neighborhoods. Population and Environment, Volume 5, p. 242-264. Available from: http:// dx.doi.org/10.1007/BF01257073

[26] LOEWEN, L. J., STEEL, G. D. \& SUEDFELD, P., (1993) Perceived safety from crime in the urban environment. Journal Environmental Psychology, 13(4), pp. 323-331. Available from: http://dx.doi.org/10.1016/S0272-4944(05)80254-3

[27] M. VIJAYKUMAR \& C.CHANDRASEKAR, (2011) Evolution of Micro, Macro, Me so Level Simulations for Spatial Analysis of Burglary in Metropolis Using Crime Mapping and GIS. International Journal of Soft Computing and Engineering, 1(5).

[28] MACDONALD, J. E. \& GIFFORD, R., (1989) Territorial cues and defensible space theory: The burglar's point of view. Journal of Environmental Psychology, 9(3), p. 193-205. Available from: http://dx.doi.org/10.1016/S0272-4944(89)80034-9

[29] MERRY, S. E., (1981) Urban Danger: Life in a Neighborhood of Strangers. s.1.:Temple University Press.

[30] MOFFAT, R., (1983) Crime Prevention Through Environmental Design - A Management Perspective. Canadian Journal of Criminology, 25(Part 4), pp. 19-31.

[31] MOTOYAMA, T., MURRAY, C., ROUSE, W. V. \& RUBENSTEIN, H., (1980) Link Between Crime and the Built Environment - The Current State of Knowledge, Volume 1. Rockville, United States of America: National Institute of Justice, US Department of Justice.

[32] NALLA, M. K., JOHNSON, J. D. \& HAYES-SMITH, R., (2011) Prior Victimization, Region, and Neighborhood Effects on Fear of Crime in Mumbai, India. Asian Criminology, Volume 6, p. 141-159. Available from: http://dx.doi.org/10.1007/s11417-011-9114-y 
[33] NASAR, J., FISHER, B. \& GRANNIS, M., (1993) Proximate physical cues to fear of crime. Landscape and Urban Planning, Volume 26, pp. 161-178. Available from: http://dx.doi. org/10.1016/0169-2046(93)90014-5

[34] NASAR, J. L., (1988) Visual preferences in urban street scenes: a cross-cultural comparison between Japan and the. In: Environmental aesthetics. United States: Cambridge University Press, pp. 260-274. Available from: http://dx.doi.org/10.1017/CBO9780511571213; http:// dx.doi.org/10.1017/CBO9780511571213.025

[35] NEWMAN, O., (1972) Defensible Space; Crime Prevention Through Urban Design. New York: Macmillan publishing company.

[36] NEWMAN, O., (1996) Creating Defensible Space, Washington, D.C.: U.S. Department of Housing and Urban Development,Office of Policy Development and Research.

[37] PAULSEN, D. J. \& ROBINSON, M. B., (2004) Spatial Aspects of Crime: Theory and Practice. New York : Pearson Education.

[38] RAMSAY, M., (1991) The effect of better street lighting on crime and fear: A Review, London: Crime Prevention Unit Papers.

[39] SAMUELS, R., (2011) CPTED Framework:Public Realm - Scoping Paper, s.1.: The Department of Justice and Attorney General New South Wales.

[40] SCHNEIDER, S. \& PEARCEY, P., (1996) The theory and practice of crime prevention through environmental design: A literature review.

[41] SHAFEEQ, B. M. A. \& BINU, V., (2014) Spatial Patterns of Crimes in India using Data Mining Techniques. International Journal of Engineering and Innovative Technology, 3(11).

[42] SHERMAN, L., GARTIN, P. R. \& BUERGER, M. E., (1989) Hot Spots of Predatory Crime: Routine Activities and the Criminology of Place. Criminology, Volume 27, pp. 27-55. Available from: http://dx.doi.org/10.1111/j.1745-9125.1989.tb00862.x

[43] SHERMAN, L. W., (1995) Hot Spots of Crime and Criminal Careers of Places. In: D. W. JOHN E. ECK, ed. Crime and Place. Monsey, New York: Criminal Justice Press, pp. 35-65.

[44] SOOMEREN, P. V., (2002) The European standard for the reduction of crime and fear of crime by urban planning and building design. Athens, Greece, s.n.

[45] SORENSEN, D., (2003) The Nature and Prevention of Residential Burglary: A Review of the International Literature with an Eye Towards Prevention in Denmark, Denmark: Denmark's Ministry of Justice.

[46] SUBBAIYAN, G. \& TADEPALli, S., (2012) An Investigation of the Relationship between Features of Bus Shelters and Fear of Crime at Bus Stops. The IUP Journal of Architecture, 4(1), pp. 54-63.

[47] TAYLOR, R. B., (1999) The Incivilities thesis: Theory, measurement, and policy. In: Measuring What Matters. Washington, D.C: National Institute of Justice/Office of Community Oriented Policing Services, pp. pp 65-88.

[48] TAYLOR, R. B., GOTTFREDSON, S. D. \& BROWER, S., (1981) Territorial cognitions and social climate in urban neighborhoods. Basic and Applied Social Psychology, 2(3), p. 289-303. Available from: http://dx.doi.org/10.1207/s15324834basp0204_5

[49] TAYLOR, R. B., SHUMAKER, S. A. \& GOTTFREDSON, S. D., (1985) Neighborhoodlevel links between physical features and local sentiments: Deterioration, fear of crime, and confidence. Journal of Architectural Planning and Research, Volume 2, pp. 261-275.

[50] WILSON, J. Q. \& KELling, G., (1982) Broken Windows. Atlantic Monthly, Volume 211, p. 29-38.
Managing Security in the Built Environment - A Review of Environmental Crime Prevention Strategies 